distance. The roof was bad, and required timbering. A long account of the Wealden iron industry is given by C. Gould in the Geological Survey Memoir "The Geology of the Weald" (1875), compiled by Topley, and additional information, notably an analysis of the Snape Wood ore, in the Geological Survey's "Special Reports on the Mineral Resources of Great Britain", 12 (1920). This analysis, made in 1908 for J. W. Gregory by Messrs. R. R. Tatlock and Thomson, showed the following, in percentages: $\mathrm{FeO}, 30.42$; $\mathrm{Fe}_{2} \mathrm{O}_{3}, 10 \cdot 10 ; \mathrm{SiO}_{2}, 26 \cdot 10 ; \mathrm{CaO}, 0 \cdot 86 ; \mathrm{SO}_{3}, 0 \cdot 06$. These show about 30.66 per cent of metallic iron, but the high percentage of $\mathrm{SiO}_{2}$ would prevent the use of this stone as an iron ore. On the contrary, the Ashburnham ore showed $\mathrm{FeO}, 42.08 ; \mathrm{Fe}_{2} \mathrm{CO}_{3}$, $6 \cdot 85 ; \mathrm{SiO}_{2}, 6 \cdot 46 ; \mathrm{CaO}, 3 \cdot 87 ; \mathrm{SO}_{3}, 0 \cdot 2$; giving $37 \cdot 49$ per cent of metallic iron, with relatively little silica. Unfortunately not only are the beds of ore thin, but they are also very irregular in their composition, and there seems little prospect that ore of this kind, which occurs in thin beds and can only be excavated together with a large amount of shale, could be profitably worked by existing methods. The usable reserves of iron ore in the Weald are, in the present circumstances, negligible.

\section{Awards of the Geological Society of London}

THE following awards of the Geological Society of London have recently been announced: Wollaston Medal to Prof. R. A. Daly, Sturgis Hooper professor of geology in the Museum of Comparative Geology at Harvard University, in recognition of his fundamental researches in many branches of geology, especially those concerned with the origin of igneous rocks, the constitution of the interior of the earth, and the controls of coral-reef formation; Murchison Medal to Prof. H. H. Swinnerton, professor of geology in University College, Nottingham, for his stimulating contributions to the philosophy of palæontology; Lyell Medal to Mr. W. S. Bisat, for his studies in the stratigraphical palæontology of Carboniferous rocks ; Wollaston Fund to Dr. E. S. Hills, for his contributions to Australian palæontology and geology; Murchison Fund to Dr. K. C. Dunham, for his investigations into the mineral deposits of the North of England; a moiety of the Lyell Fund to Dr. S. R. Nockolds, for his mineralogical and petrological work and his contributions to the study of assimilation processes; a second moiety of the Lyell Fund to Dr. J. Shirley, for his researches in palæozoic palæontology and stratigraphy.

\section{Institute of Metals : Platinum Medallist}

THE Platinum Medal of the Institute of Metals for 1942 has been awarded to Mr. W. Murray Morrison, vice-chairman and managing director of the British Aluminium Co., in recognition of his outstanding services to the non-ferrous metals industries. $\mathrm{Mr}$. Morrison is an original member and a fellow of the Institute of Metals, on the Council of which he served for sixteen years-in the last two as vicepresident. He may be described as the father of the aluminium industry in Great Britain, having been associated with the British Aluminium Co. since its inception in 1894. $\mathrm{He}$ is also the pioneer of the developments of Highland water-power upon which depend the electro-metallurgical operations for the production of aluminium at three great Scottish factoriss.
Institution of Mining and Metallurgy: New President

Mr. J. Alles Howe has been elected president of the Institution of Mining and Metallurgy for the year 1942-43. Mr. Allen Howe was educated privately and at the Royal College of Science, and holds the London B.Sc. degree. For a year he was demonstrator in geology at the Royal College of Science and Royal School of Mines, and in 1901 was appointed to H.M. Geological Survey, where he served for thirty years on the field staff and as curator of the Museum of Practical Geology, and from 1922 onwards as assistant director. During his service he took an active part in stimulating the economic side of the Survey's work, and he is the author of several works mainly dealing with building stone, broken stone, and refractory materials. On these and other subjects he has made numerous contributions, including many articles on topographical geology and stratigraphy in the Encyclopædia Britannica (thirteenth edition). He was a member of the International Conferences on Testing Materials, and was for a number of years adviser on stone to H.M. Office of Works and since 1918 to the Imperial War Graves Commission. He was a member of the Committee on Coal Conservation and the Imperial Economic Committee. Since $1931 \mathrm{Mr}$. Allen Howe has practised as a consultant in economic geology.

\section{Chronica Botanica}

THIs international plant science news magazine, formerly published in Holland, continues to appear now from Waltham, Mass., U.S.A. Vol. 6, Nos. 17-18 appeared in November 1941 and is an exceedingly interesting number. Under the heading "Nomina ad Infinitum" Dr. F. C. Bawden asks for a more vigorous effort to rationalize procedure in the naming of virus diseases of plants, and then in the "Plant Science Forum" a number of subjects of general botanical interest are raised by well-qualified contributors. Very general interest will be aroused by a brief note from Dr. W. C. Darrah on the fossil embryos in Iowa coal balls; in particular, in the record of the discovery of the embryo and young seedling of a Lepidocarpon. There then follows a series of brief "Progress Reports" on plant science in Latin America, for example, on forestry in Mexico (Meyer), natural resources of Costa Rica (Skutch), etc.

International activities naturally do not bulk largely in the present day, but there is a note on the International Forestry Centre, which, established in May 1939 as a division of the International Institute of Agriculture, held its third meeting in March 1940 in Berne. The "Chronicle" of events has a very full statement of Kew activities in view of the centenary of the Royal Botanic Gardens in 1941: there is an interesting account also of the All-Union Agricultural Fair held in Moscow during 1939 and 1940 and again re-opened in the early summer of 1941. Details of the activities and vicissitudes of various botanical departments under present disturbed conditions make interesting reading to botanists, and similarly the many changes in personnel chronicled will often bring news of colleagues to readers. Very naturally the editors have contemplated closing this venture with the completion of vol. 6, and the extension of the War to the Pacific will possibly force them to reconsider their present decision to proceed at least with the issue of Vol. 7 in the form of twelve numbers to be issued once every 